\title{
当センターで発見されたダブルキャンサーの一例について (早期胃癌発見のための技術的考察)
}

$\begin{array}{lrrr}\text { 佐藤 } & \text { 恵一 } & \text { 島田 } & \text { 雅彦 } \\ \text { 磯崎 } & \text { 孝 } & \text { 相馬 } & \text { 勇七 } \\ \text { 泉 } & \text { 將 } & & \end{array}$

\section{目 的}

近年, 内視鏡に代わられつつある胃 $\mathrm{X}$ 線検査ではあ るが, 早期癌発見のためにはその重要度は依然として 高い。当センターのドックで発見されたダブルキャン サーの症例から, 胃 X 線検査撮影法について報告をす る。

\section{対 象}

半年前に当センターを受診し, 胃 X 線検查を実施し たが, 異常を指摘されなかった (患者：58 歳, 男性, 主訴：特になし)。その後, ドックで胃ルーチン検査を 行ったところ, 穹蕯部と胃角部に異常が認められた。 生検の結果グループVと診断された。

\section{方 法}

当センターではルーチン撮影として, 食道二重造影 像二分割, 背臥位二重造影正面像, 同じく第 1 斜位像, 腹臥位二重造影正面像, 立位充盈正面像, 二重造影四 分割, 胃上部の撮影法として半立位二重造影像二分割, 立位圧迫像と 8 枚を基準として撮影している。体位変 換の方法は右回転を主体とした回転ローリング法を採 用している。今回発見された症例で, 穹蕯部の病変は 天板をやや水平より起こし, Ba を穹窒部から小弯側 に流し込んだとき, 浅い溜りをチェックし追加撮影を 実施した結果II c+III型の早期癌であった $(3.6 \mathrm{~cm} \times$ $1.8 \mathrm{~cm}$, 深達度 $\mathrm{Sm})$ 。穹隆部では圧迫ができないため,

$\begin{array}{llll}\text { 富山 } & \text { 芳丈 } & \text { 永田 } & \text { 京子 } \\ \text { 清水 } & \text { 利雄 } & \text { 田代 } & \text { 昭男 }\end{array}$

$\mathrm{Ba}$ をよく付着させた二重造影が必要であり, 透視で 異常をチェックしたなら Ba の丹念な流し込みを行う ことが大切である。また胃角部の病変は同じく透視下 で胃粘膜の凹凸をチェック，その後スポット及び圧迫 にて追加撮影をした。病理検査の結果広範囲な II c十 II b 型の早期癌であった $(8.5 \mathrm{~cm} \times 5.5 \mathrm{~cm}$, 深達度 $\mathrm{m})$ 。胃角部は十二指腸から $\mathrm{Ba}$ が流出して重なりやす いため, 異常所見をチェックしたなら早めに撮影した 方がよい。また $\mathrm{Ba}$ が病変に重なった場合は体位変換, 呼吸により $\mathrm{Ba}$ と病変とを分離させて撮影をする。

\section{結 果}

早期癌を発見するためのポイントとして，とにかく 十分に体位変換をして Ba を胃壁へ付着させることが 必要である。次に Ba は小腸との重なりを避けるため, できるだけ十二指腸へ流出させないような体位変換を 心掛ける。透視下では, Ba の流れを必ず目で追い小さ な凹凸にも注意を払い，異常所見を発見したならでき るだけ追加撮影をする。また病変は 1 つとは限らない ため, 胃全体をくまなくチェックすることが大切であ る。

最後に限られた時間内に透視下で異常所見をチェッ クし, 撮影することは大変困難であるが, これらのポ イントを踏まえて撮影に対する熱意を持つことが早期 癌発見の向上につながると思われる。

A Case of Double Cancer Detected in I. M. C (Technical Study for Detection of the Upper Gastric Early Cancer)

茨城県メディカルセンター 